\title{
City Transformation is the Biggest Development-The Exploration and Reflection by Taking City Village Transformation as the Urbanization Path
}

\author{
Hui Zhang \\ Department of Economics and Management, Jining University, Qufu, 273155, China
}

Keywords: City Village Transformation; Regional Governance; Local Governemnt Governance; Path Restriction; Theoretical Measures.

\begin{abstract}
Along with the constant development of economy, more and more housing problems in cities become the new topic perplexes people's lives as people are enjoying the fast pace and high enjoyment brought by economy. During the management process of the cities, the launch and advocate of urbanization path are not only the great innovation of platform contents, but also concern the development in our country, which promotes the government officials to form an efficient path with advanced value. This text firstly states the connotation of the city village transformation of the local government and analyzes the causes for the development of city village transformation. Based on that, current government officials must master the development situation of the urbanization path. This text further explores the effective measure to carry out city village transformation on the platform of local government.
\end{abstract}

\section{Introduction}

For a long time, our country takes the economic interests as the center during the process of economic and social development and under the governance of this value, human activities conduct predatory utilization and development toward the factors such as resources and environment. Although, the economy in our country has gained rapid development and the international competitiveness has been enhanced remarkably, new problems occur along with one-sided demand of human. The destructive effects brought by housing problems in cities and city village have more and more influence on human. Coupled with the city pressure caused by inappropriate transformation, various irreversible disasters happen frequently including the increased temperature of the whole city and country, resources shortage and species extinction, which influences the production and lives of the people in cities and villages. Based on this consideration, we should focus on the local government governance and carry out the value governance of the urban villages toward the government officials under the background of regional governance based on the transformation of city village. In this way, it can improve people's ideological understanding, which helps restrain and ease the contradiction between people and city village effectively. At the same time, the value governance of city villages on the platform of local government are coordinated with the civilized construction, economic construction, political construction, cultural construction and social construction put forward by the Party's $18^{\text {th }}$ Report. The entire allocation of the integrated five factors to construct the socialism with Chinese characteristics is supplementary to each other. ${ }^{[1]}$ This constitutes the important dimensions of the current urbanization process. In our opinion, the main goal of local government governance is to convey talents in such areas as city construction and city village transformation for the society in order to promote the urbanization process better and make more people enjoy the benefits brought by the urbanization. From this perspective, the government officials in our country, which are the important participants and constructer of the regional governance based on the city village transformation, must launch the value governance of the city villages in time and play their role of optimistic leading well. At the same time, this also provides new thought for the course reform of the local government and is the perfect innovative measure of the platform of local government. 
The Connotation of the City Village Transformation of the Local Government under the Vision of Regional Governance of City Village Transformation.

\section{The Basic Connotation for Constructing the Regional Governance based on City Village Transformation}

Along with the constant development of economy in our country, more and more housing problems in cities and city villages have triggered the wide concern from the society and working hard to construct the regional governance based on the city village transformation becomes the needs of development in the new period. What needs to be pointed out especially is: our country is a socialist country so the advocate of regional governance based on the city village transformation is to construct the socialist regional governance based on the city village transformation which is the socialist value following the outstanding traditional culture such as Marxism-Leninism and Mao Zedong thought. Therefore, the construction of socialist regional governance based on the city village transformation in our country has its own characteristics and connotation: the first is the harmony of itself, the second is the harmony among the people, the third is the harmony between the society and city village, the fourth is the harmony among the various systems and social classes in the society, the fifth is the harmony between the whole world and the outside world. The main contents of the regional governance based on the construction of city village transformation, which should center closely on the basic characteristics of socialism in our country, is to build the society with democracy and law, fairness and justice, honesty and fraternity, vitality, peace and order and harmonious existence between human and city villages.

The Connotation of City Village Transformation of the Local Government

As is known to all, the urbanization in our country is the urbanization of human. The governance launched by the local government is the supplement to citizen governance while the goal of governance is mainly to exert influence on certain classed, parties, social(groups) or individuals so as to promote the social development efficiently and satisfy the socialist practices in our country. The governance contents launched by the local government only focus on world outlook, political view, view of life, legal idea and moral outlook. As country, society and individual keep improving their attention about the housing in cities and the city villages to confirm to the requirement of era development, implementing the governance of city village value during the governance of city academics becomes one the main contents. The government officials' penetration and value of the governance of city village value in the governance means that on the platform of governance, government officials impart the theory of city village to the government officials purposefully and designedly to help them set up the right concept of city village and form favorable behavior habit of city village. This further transfers the city village entirely or partly into a part of city construction and development and also the residents in city villages become an indispensible part of the whole city.

\section{The Importance and Current Situation of the Government's Urbanization Path}

\section{The Importance of the Cultural Field and Urbanization Path of Local Government Based on City Village Transformation}

Along with the constant development of the economic society in our country, more and more governance problems related to the application of new technology have triggered the wide attention in the society. Working hard to construct the regional governance based on city village transformation becomes the needs of the development during the new period. For urbanization path of local government, the material in which city governance advocates harmony is the inevitable requirement of regional governance of city village based on city village transformation and does not violate the socialist value following the excellent traditional culture. In other words, the construction of regional governance based on city village transformation is beneficial for the diversion of basic connotation characteristics and connotation in the society. While for the urbanization path of city governance, the contents in the regional governance based on city village transformation should center closely on the basic characteristics of governance during the harmonious period. As is known 
to all, urbanization path of city governance is the managers' supplement toward the governance during the period of middle school while one of the main goal of governance is to form some kinds of cultural influence on the capacity formation of certain social(groups) or individuals. Then cultural values and academic standard which confirms to the society can be formed to promote the development of a international society effectively.

The Requirement and Current Situation of Regional Governance Based on City Village Transformation toward Urbanization Path of Local Government

First of all, the construction of regional governance based on city village transformation helps promote the contents renewal of the urbanization path of local government. Although traditional urbanization path of local government has systematic course planning and rich contents in aspects of management and exerts optimistic influence on the management of the managers, along with the industrial revolution and reform practice, there exists destructive relationship between harmonious existence and human relationship. Harmonious existence restricts the continuous development of management and governance in our country and the solution of harmonious existence has become one of the main topics for human exploration. Only by rediscovering the current relationship between harmonious existence and the realization of city village value and further improving human behavior can the construction of regional governance based on city village transformation and the modernity of materials in our country be guaranteed. Secondly, the construction of regional governance based on city village transformation builds a favorable urban residence for the citizen governance and harmonious governance. The urbanization path of local government with harmonious existence requires the effective guarantee of management atmosphere and urban residence. As the important factor constituting the governance, city governance has caught more and more attention and the great idea of the construction of regional governance based on city village transformation brought up from our government provide good guarantee of urban residence for the penetration and harmonious governance for the urbanization path of local government. ${ }^{[6]}$ The general public can feel the culture based on city village transformation well in the urban residence governed by the local government and can always feel the local government's publicity efforts about life and urban residence. On the one hand, the construction of hardware facility in the local government should be strengthened and on the other hand, the propaganda of harmonious existence should be emphasized to affect and influence the citizen group from material and spirit level so as to make them feel the necessity of harmonious governance in harmonious interpersonal relationship. When being specific to the citizen group's understanding about the current situation of urbanization path of local government from the construction of regional governance based on city village transformation, we think that the main goal for the citizen group to accept the governance is to adapt to the requirement of social development while in the urbanization path of local government under the philosophy of regional governance based on city village transformation, the enhancement of governance of harmonious existence is conducive to the proper handling and improvement of the citizen group's behavior quality and scientific awareness. In addition, it promotes the value of the citizen group and puts the consciousness into the daily activities of the citizens early. Also the citizen group can master advanced scientific knowledge and their comprehensive development is facilitated. From the current situation, this is very important.

\section{The Reinforcement of the Measure for City Village Transformation under the Background of Regional Governance Based on City Village Transformation.}

\section{Enriching the Contents of City Village Transformation and Improving the Shift of Practice}

The reinforcement of the city village transformation of the local government needs further enhancement of the management of related knowledge concerning Marxism. The value of city village is the further enrichment of Marx's world outlook, life outlook and value. It can guide the citizens to master related knowledge and improve the ideological understanding of government officials so as to influence the daily behavior of government officials. During the daily perfecting process, the related knowledge should be conducted a more careful exploration and the related knowledge about city 
inhabitancy in city villages, protection of urban residence and the technological governance of resource utilization should be linked closely to carry out the political governance of city village value and try to construct related theoretical system. On the one hand, the citizens should be imparted with the basic knowledge of city village on the platform such as the contents including knowledge of city village, law and regulations of city village(Senfu Law and Urban Residence Protection Law). At the same time, government officials should carry out efficient interaction by aiming at people's daily life and the contents need to be innovative. Also, the advanced urbanization path from abroad should be learned from. In the meantime, the citizens should be guided to set up a continuous and advanced scientific idea on the platform of governance and the cultivation and governance of city village consciousness for the government officials should be valued to form a scientific understanding and improve the practical ability of the citizens.

\section{Reinforcing the Production of Life Meaning and Adopting the Diversified Improvement Method}

First of all, during the perfecting process, the perfecting mode combined with theoretical perfection and practical perfection should be adopted. When the government officials are launching the perfecting process, they should change their thought, update their idea and stick to citizen-oriented. During the process of city village transformation, on the one hand, related theoretical perfection should be valued to increase the ideological understanding of the citizens and in the meantime, the cultivation of the citizens' piratical ability should be emphasized. The government officials not only make the citizens manage the theoretical knowledge related to city village and urban residence protection, but also guide and encourage them to participate in social practice of the daily urban residence protection. Secondly, during the perfecting process, government officials should adhere to the combination of platform governance and the self-governance of the citizens. On the platform, government officials should dare to advance with the times, put forward the newest cases concerning the aspects of urban residence in city villages and proceed the evaluation. They should also encourage citizens to provide their own views about the cases and improve the self management ability of the citizens by taking advantages of media resources such as internet. Then they increase public's understanding about the urban residence protection in city villages through the form of sharing and communication on the platform. The goal can be better realized and perfected through the promotion of communication enthusiasm of the citizens.

\section{Building Favorable Urban Residence and Perfecting the Attractiveness of Ideology}

Ideology means the ideological system in certain social structure which can guide the public's statements and actions. We neither improperly belittle ourselves to stay on the framework of western discourse nor boast wildly about ourselves with eastern discourse-especially the speech in ancient discourse in China and the statements about the perfecting process of modern urbanization path. During the process of city village transformation, the penetration of city village value should be emphasized in the cultural construction of local government so that the city village value can provide a good management atmosphere for the citizens by relying on the cultural construction platform of local government. First of all, we should deepen the city village smell into the material cultural construction of local government little by little. For example, posting slogans such as 'taking care of city village, protecting urban residence, improving awareness of environmental protection and co-constructing a beautiful local government in places where government officials come in and out frequently such as construction design of local government, facility instrument, activity space, afforestation of local government and the improvement of dormitory building can well reflect the strong city village smell. ${ }^{[5]}$ At the same time, the construction of spiritual culture as well as cultural construction of local government should be valued. Apart from the existence of slogans, it should also be reflected in daily behavior. Favorable management atmosphere should be built through the activities such as the propaganda of the urban residence in city villages, cultural festival for the protection of local government and cultural weeks. The advantages of the management of urban residence and the abundant practical activities of citizens are bound to have optimistic effect. 


\section{Conclusion}

In conclusion, under the background in which our country are working hard to build regional governance based on city village transformation, the city village transformation carried out from the local government governance has great significance. The construction of the regional governance based on city village transformation and the city village transformation are closely related and influence each other. At present, there still exist problems such as the lack of governance contents, the single form perfection and the perfection of poor urban residence in the city village transformation of the local government in our country. Aiming at the insufficient pertinence, we put forward the city village transformation and reinforce the innovative measures in aspects of contents, form, and the construction of urban residence. But if we want to solve the problems completely and radically, we still need continuous exploration from the practices of related practitioners.

\section{References}

[1] Liaoyun. The Construction Work under the Background of Regional Governance of City Village Transformation. Journal of Hubei Nationalities University(Natural Science) , 2011(05).

[2] Shen Haizhuang. The Study of Governance Effectiveness. Wuhan Government Press. 2012.

[3] Liu Zenghui. Marxism City Village Ideology and Practical Study. Beijing: Government Press of Beijing Normal University, 2012.

[4] Li Zhenghua.The New Principle of the Government Officials' Governance. Journal of Hubei Nationalities University(Natural Science), 2011(04).

[5] Shi Guoliang. The Discussion of the Governance Innovation of Government Officials under the New Situation. Youth Studies, 2011(01). 